\title{
The effect of dietary lipid saturation and monensin-Na on the CLA content of lambs' meat
}

\author{
A.N. du Toit ${ }^{1}$, O.B. Einkamerer ${ }^{1 \#}$, A. Hugo ${ }^{2}$, H.J. van der Merwe ${ }^{1}$ \& M.D. Fair ${ }^{1}$ \\ ${ }^{1}$ Department of Animal, Wildlife and Grassland Sciences; ${ }^{2}$ Department of Microbial, Biochemical and Food \\ Biotechnology; ${ }^{1,2}$ Faculty of Natural and Agricultural Sciences, University of the Free State, P.O. Box 339, \\ Bloemfontein 9300, South Africa
}

(Received 30 September 2012; Accepted 3 July 2013; First published online 6 August 2013)

Copyright resides with the authors in terms of the Creative Commons Attribution 2.5 South African Licence.
See: http://creativecommons.org/licenses/by/2.5/za/
Condition of use: The user may copy, distribute, transmit and adapt the work, but must recognise the authors and the South African Journal
of Animal Science

\begin{abstract}
A study was conducted to investigate the influence of an ionophore antibiotic and lipid saturation within a standard finishing diet on the conjugated linoleic acid (CLA) content of lambs' meat. Two identical sheep grower diets containing 145 g CP, 282 g NDF and 45 g EE per kg DM were formulated. One diet contained no ionophore antibiotic and the other monensin-Na included at $165 \mathrm{~g} / \mathrm{ton}$. These two basal diets were supplemented, according to a 2 x 3 factorial design, with three lipid sources [i.e. $20 \mathrm{~g} / \mathrm{kg}$ of either beef tallow, sunflower oil or a CLA oil concentrate] differing in saturation level and fatty acid profile. Sixty South African Mutton Merino lambs (31.15 $\pm 2.83 \mathrm{~kg}$ ) were randomly allocated to the six treatments. After dietary adaptation of 10 days, the lambs received their respective treatment diets for the remaining period of 51 days. At the end of the study seven lambs $(45.11 \pm 2.99 \mathrm{~kg})$ were randomly selected per treatment and slaughtered. Muscle and subcutaneous fat tissue from loin chops of each carcass were used for lipid extraction and fatty acid analysis. The supplementation of CLA oil in the diet resulted in a significantly lower vaccenic acid concentration of lamb muscle tissue. In contrast, supplementing sunflower oil increased the linoleic acid concentration of only the subcutaneous fat tissue significantly. Sunflower- and CLA oil supplementation increased the cis-9, trans-11 CLA isomer of both subcutaneous fat and muscle tissues, whereas only the CLA concentrate increased the trans-10, cis-12 isomer of both mentioned tissues significantly. The dietary inclusion of monensin-Na decreased the vaccenic-, linoleic- and CLA (cis-9, trans-11 isomer) concentrations of both lamb subcutaneous fat and muscle tissues significantly. The manipulation of the CLA content of lamb seems to be effective when adding either sunflower oil or a CLA oil concentrate to the finishing diet of lambs. However, this effect is inhibited by the addition of monensin-Na to the same diet.
\end{abstract}

Keywords: Conjugated linoleic acid, cis-9, trans-11 CLA isomer, tallow, sunflower oil, subcutaneous fat "Corresponding author: Einkamererob@ufs.ac.za

\section{Introduction}

The past few decades have been characterized by an increased awareness concerning the nutritional aspects and health implications of ruminant products for human consumption. There is recognition that human health benefits from the regular consumption of polyunsaturated fatty acids (PUFA). Conjugated linoleic acid (CLA) isomers, for instance, have been associated with a reduced risk of cancer (McGuire \& McGuire, 2000), cardiovascular disease and diabetes, as well as improving the immune system and bone health in animals and humans (Schmidt et al., 2006). The cis-9, trans-11 isomer seems to be the most biologically active form (Bessa et al., 2000) responsible for beneficial health effects (Rainer \& Heiss, 2004). In contrast, Wahle et al. (2004) reported in a review that the trans-10, cis-12 CLA isomer could induce an increase in isoprostane secretion in the urine of humans, an indicator of non-enzymatic eicosanoid formation and of lipid peroxidation. This same isomer could also elicit pro-carcinogenic effects on colon and prostate 
cancer, as well as increase insulin concentrations in blood plasma with an accompanying enhanced insulin sensitivity.

However, because of the positive effects, there has been increased interest in finding different ways to favourably manipulate the fatty acid composition of ruminant meat and -products. Apart from lipid supplementation (Schollan et al., 2006), limiting the ruminal biohydrogenation of fatty acids may increase its content in ruminant meat (Bessa et al., 2000). It is well documented that changes in the rumen environment lead to changes in the microbial population and microbial activity. This in turn affects the digestion of lipids in the rumen and consequently fatty acids produced due to biohydrogenation (Martin \& Jenkins, 2002).

Ionophore antibiotics have been proven to inhibit several microbial species involved in ruminal biohydrogenation (Jenkins et al., 2003). Limiting the extent of rumen lipid metabolism when supplementing ionophores led to subsequent changes in milk lipid fatty acid composition of dairy cows, where especially higher vaccenic acid (C18:1t11) and CLA concentrations were observed (Sauer et al., 1998; Bell et al., 2006). When used in conjunction with dietary PUFAs higher levels of vaccenic acid and CLA-isomers were observed in milk fat (Bell et al., 2006).

No research, however, has been conducted regarding similar effects of ionophores on the fatty acid composition of lambs' meat. Therefore, the aim of this study was to determine the effect of lipid saturation and ionophore inclusion within a standard finishing diet of lambs on the CLA content of muscle and adipose tissues.

\section{Materials and Methods}

All procedures conducted during this study were approved by the Interfaculty Animal Ethics Committee for Animal Experimentation at the University of the Free State (Animal Experiment No. 10/2010).

Two identical sheep grower diets containing $145 \mathrm{~g}$ crude protein (CP), $282 \mathrm{~g}$ neutral detergent fibre (NDF) and $45 \mathrm{~g}$ ether extract (EE) per kg DM were formulated. One diet contained no ionophore antibiotic and the other monensin- $\mathrm{Na}$, included at $165 \mathrm{~g} /$ ton according to the mean registered level of the respective supplier. These two basal diets were supplemented, according to a $2 \times 3$ factorial design, with three lipid sources [i.e. $20 \mathrm{~g} / \mathrm{kg}$ of either saturated beef tallow, unsaturated sunflower oil or an unsaturated CLA oil concentrate (containing 60\% CLA)] differing in saturation level and fatty acid profile. Sixty South African Mutton Merino lambs $(31.2 \pm 2.83 \mathrm{~kg})$ were randomly allocated to the six treatments $(\mathrm{n}=10$ lambs/treatment). After dietary adaptation (10 days) all lambs received their respective treatment diets for the remaining period of 51 days. At termination of the study seven lambs per treatment (45.1 $\pm 2.99 \mathrm{~kg})$ were randomly selected and slaughtered. Lipid from muscle and subcutaneous fat tissue of loin chops of each carcass were quantitatively extracted (Folch et al., 1957), stored in a polytop (glass vial, with push-in top) and frozen at $-20^{\circ} \mathrm{C}$ under a blanket of nitrogen, pending fatty acid analyses using gas chromatography.

The data were subjected to PROC ANOVA and analysed according to a $3 \times 2$ factorial arrangement of treatments and tested for significant differences using the General Linear Model (GLM) procedures of the SAS programme (SAS, 1999). Tukey's honest significant difference (HSD) test was used to identify significant differences $(P<0.05)$ between treatments (SAS, 1999).

\section{Results and Discussions}

The effect of dietary lipid source and ionophore inclusion on the CLA content of intramuscular- and subcutaneous fat tissue of S.A. Mutton Merino lambs are shown in Table 1. Only the major fatty acids that play a role in the biohydrogenation pathway of CLA were included.

From Table 1 it can be seen that tallow inclusion increased $(P<0.05)$ the vaccenic acid $(\mathrm{C} 18: 1 t 11)$ concentration of lamb muscle tissue, compared to the CLA treatment. Following sunflower oil inclusion, the linoleic acid $(\mathrm{C} 18: 2 \mathrm{c} 9,12 \mathrm{n}-6)$ concentration was increased $(P<0.05)$ only in adipose tissue. These effects seem to be consistent with the literature, stating that the fatty acid composition of muscle and adipose tissue is influenced by the fatty acid composition of the diet fed to ruminants (Demeyer \& Doreau, 1999); although, the effect may differ depending on the deposit site, either for muscle or adipose tissue (Oka et al., 2002). However, results in literature seem to be variable. Diets containing high levels of linoleic acid $(P<0.05)$ increased its level in lamb meat (Ivan et al., 2001), whereas Manso et al. (2009) reported no effects on Merino lamb muscle tissue. Schollan et al. (2006) mentioned that the fatty acid composition of muscle tissue is less influenced by diet than that of adipose tissue, as most of the fatty acids are located in phospholipids 
and cellular membranes (Wood et al., 2008). Their fatty acid composition is fairly stable in order to ensure normal membrane function and thus cellular metabolism (Jerónimo et al., 2009).

Table 1 The effect of dietary lipid source and ionophore inclusion on the fatty acid composition of muscleand adipose tissue of S.A. Mutton Merino lambs (means)

\begin{tabular}{|c|c|c|c|c|c|c|c|c|c|}
\hline \multirow{2}{*}{ Parameter } & \multicolumn{3}{|c|}{$\begin{array}{l}\text { Lipid source } \\
(20 \mathrm{~g} / \mathrm{kg})\end{array}$} & \multicolumn{2}{|c|}{$\begin{array}{l}\text { Ionophore } \\
\text { (165 g/ton) }\end{array}$} & \multicolumn{3}{|c|}{$\begin{array}{c}\text { Significance } \\
\text { (P-value) }\end{array}$} & \multirow{2}{*}{$\mathrm{CV}$} \\
\hline & Tallow & $\begin{array}{c}\text { Sunflower } \\
\text { oil }\end{array}$ & $\mathrm{CLA}^{\#}$ & $\begin{array}{c}\text { Not } \\
\text { included }\end{array}$ & Included & $\begin{array}{c}\text { Lipid } \\
\text { source }\end{array}$ & Ionophore & Interaction & \\
\hline \multicolumn{10}{|c|}{ Muscle tissue (\% of total fatty acids) } \\
\hline Fat content (\%) & 3.97 & 4.63 & 4.31 & 4.10 & 4.51 & 0.1781 & 0.1493 & 0.5442 & 19.5 \\
\hline Vaccenic acid & $1.43^{\mathrm{a}}$ & $1.31^{\mathrm{ab}}$ & $1.20^{\mathrm{b}}$ & $1.38^{1}$ & $1.24^{2}$ & 0.0003 & 0.0013 & 0.4498 & 9.1 \\
\hline Linoleic acid & 3.80 & 3.90 & 3.72 & $4.19^{1}$ & $3.42^{2}$ & 0.8629 & 0.0072 & 0.5429 & 21.0 \\
\hline $\mathrm{CLA}^{\#}(\mathrm{c} 9, \mathrm{t} 11)$ & $0.57^{\mathrm{a}}$ & $0.76^{\mathrm{b}}$ & $0.79^{\mathrm{b}}$ & $0.83^{1}$ & $0.58^{2}$ & 0.0015 & $<0.0001$ & 0.7755 & 20.5 \\
\hline $\mathrm{CLA}^{\#}(\mathrm{t} 10, \mathrm{c} 12)$ & $0.00^{\mathrm{a}}$ & $0.00^{\mathrm{a}}$ & $0.07^{\mathrm{b}}$ & 0.03 & 0.02 & 0.0060 & 0.5372 & 0.6807 & 243.1 \\
\hline \multicolumn{10}{|c|}{ Subcutaneous fat tissue (\% of total fatty acids) } \\
\hline Fat content (\%) & 74.5 & 74.6 & 75.4 & 74.9 & 74.7 & 0.7388 & 0.8400 & 0.2823 & 4.0 \\
\hline Vaccenic acid & 1.15 & 1.16 & 1.06 & $1.22^{1}$ & $1.03^{2}$ & 0.1747 & 0.0002 & 0.1057 & 12.2 \\
\hline Linoleic acid & $2.18^{\mathrm{a}}$ & $3.16^{\mathrm{b}}$ & $2.30^{\mathrm{a}}$ & $2.69^{1}$ & $2.41^{2}$ & $<0.0001$ & 0.0457 & 0.5855 & 16.0 \\
\hline CLA $(\mathrm{c} 9, \mathrm{t} 11)$ & $0.68^{\mathrm{a}}$ & $1.00^{\mathrm{b}}$ & $1.09^{\mathrm{b}}$ & $1.12^{1}$ & $0.73^{2}$ & 0.0009 & $<0.0001$ & 0.4586 & 26.9 \\
\hline CLA (t10, c12) & $0.00^{\mathrm{a}}$ & $0.00^{\mathrm{a}}$ & $0.16^{\mathrm{b}}$ & 0.05 & 0.05 & $<0.0001$ & 0.5182 & 0.6561 & 26.5 \\
\hline
\end{tabular}

a,b Row means with different superscripts differ $(P<0.05)$ within lipid source.

1,2 Row means with different superscripts differ $(P<0.05)$ within ionophore inclusion.

CLA: conjugated linoleic acid; CV: coefficient of variation (\%).

The addition of sunflower oil and a CLA concentrate in the finishing diets of lambs increased ( $P$ $<0.05)$ the cis-9, trans-11 CLA-isomer of both muscle- and adipose fat tissue of lambs compared to those fed the tallow diets (Table 1). This significant increase occurred despite the fact that beef tallow contains very low quantities of the mentioned isomer, whereas the same isomer was not detected within the sunflower oil treatments. This result corresponds with most studies where linoleic acid rich lipid sources were supplemented in ruminant diets (Ivan et al., 2001; Wynn et al., 2006). Conjugated linoleic acid is produced by different bacterial species in the rumen through the isomerisation of linoleic acid, but also through the endogenous synthesis in body tissues from vaccenic acid via $\Delta 9$-desaturase enzymes (Woods \& Fearon, 2009). After the isomerisation of linoleic acid in the rumen, the cis-9, trans-11 CLA-isomer is rapidly hydrogenated to vaccenic acid (Bauman et al., 1999). The increase of CLA was expected since the sunflower oil diet contained much more linoleic acid compared to the other treatments. The available vaccenic acid content within muscle tissue could also be de-saturated to the cis-9, trans-11-isomer of CLA (Schmidt et al., 2006), thereby possibly lowering the vaccenic acid concentration within the same tissues. It is, however, not clear if this was the case in the present study since the CLA concentration of lamb tissue could also originate from the absorbed CLA formed in the rumen (biohydrogenated) (Schmidt et al., 2006).

The addition of the CLA concentrate in the finishing diet of lambs also increased $(P<0.05)$ the trans10, cis-12 CLA-isomer of both muscle- and adipose fat tissue compared to the other treatments (Table 1). However, the trans-10, cis-12-isomer of CLA cannot be synthesized by animal tissues (Raes et al., 2004) and therefore could only originate from a dietary source. Manso et al. (2009) mentioned that some studies have, however, recorded significant increases in muscle- and/or adipose tissue trans-10, cis-12-CLA concentration after including linoleic acid rich supplements in the diets of lambs. Yet, this was not the case in the present study.

From the results in Table 1 it further seems that monensin-Na inclusion in the finishing diets of lambs decreased $(P<0.05)$ the vaccenic acid, linoleic acid, as well as the cis-9, trans-11 CLA-isomer concentrations 
of both muscle- and adipose tissue. This decrease may be attributed to the significant $(P<0.005)$ lower dry matter feed intake (DMI) of lambs observed for the basal diets supplemented with monensin-Na, compared to no supplementation (1546 vs. 1685 g/day, respectively). This probably led to a decrease in total available fatty acid substrate intake for possible deposition in animal tissues.

As explained earlier, the decrease in the cis-9, trans-11 CLA concentration of lamb muscle tissue following monensin-Na inclusion in the present study was unexpected. The reason for the negative effects of monensin-Na supplementation on both CLA and vaccenic acid content of lamb meat found in the study is unclear. Besides the negative effect on intake and therefore less available substrate, it might also be that monensin-Na has unknown effects on the metabolism and consequent deposition of CLA in lambs' meat. This view is supported by research where rumen independent monensin administration has been shown to alter insulin, free fatty acids (FFA), glucose, as well as several mineral levels in ruminant plasma; thus, indicating metabolic effects independent of changes in ruminal metabolism (Armstrong \& Spears, 1988).

\section{Conclusion}

Results indicated that the fatty acid profile of lambs can be manipulated by the inclusion of alternate lipid sources in the diet. The manipulation of the CLA content of lambs seems to be effective when adding either sunflower oil or a CLA oil concentrate to the finishing diet of lambs. This effect is, however, negatively affected by the addition of monensin to the same diet.

\section{Acknowledgements}

The authors wish to acknowledge Nutri Feeds for their financial support during this study.

\section{References}

Armstrong, J.D. \& Spears, J.W., 1988. Intravenous administration of ionophores in ruminants: Effects on metabolism independent of the rumen. J. Anim. Sci. 66, 1807-1817.

Bauman, D.E., Baumgard, L.H., Corl, B.A. \& Griinari, J.M., 1999. Proc. Am. Soc. Anim. Sci., 1-15.

Bell, J.A., Griinari, J.M. \& Kennelly, J.J., 2006. Effect of safflower oil, flaxseed oil, monensin and vitamin $\mathrm{E}$ on concentration of conjugated linoleic acid in bovine milk fat. J. Dairy Sci. 89, 733-748.

Bessa, R.J.B., Santos-Silva, J., Robeiro, J.M.R. \& Portugal, A.V., 2000. Reticulo-rumen biohydrogenation and the enrichment of ruminant edible products with linoleic acid conjugated isomers. Livest. Prod. Sci. 63, 201-211.

Demeyer, D. \& Doreau, M., 1999. Targets and procedures for altering ruminant meat and milk lipids. Proc. Nutr. Soc. 58, 593-609.

Folch, J., Lees, M. \& Sloane-Stanley, G.H., 1957. A simple method for the isolation and purification of total lipids from animal tissue. J. Biol. Chem. 226, 497-509.

Ivan, M., Mir, P.S., Koenig, K.M., Rode, L.M., Neill, L. \& Mir, Z., 2001. Effects of dietary sunflower seed oil on rumen protozoa population and tissue concentration of conjugated linoleic acid in sheep. Small Rumin. Nutr. 41, 215-227.

Jenkins, T.C., Fellner, V. \& McGuffey, R.K., 2003. Monensin by fat interaction on trans fatty acids in cultures of mixed ruminal microorganism grown in continuous fermenters fed corn or barley. J. Dairy. Sci. 86, 324-330.

Jerónimo, E., Alves, S.P., Prates, J.A.M., Santos-Silva, J. \& Bessa, R.J.B., 2009. Effect of dietary replacement of sunflower oil with linseed oil on the intramuscular fatty acids of lamb meat. Meat Sci. 83, 499-505.

Manso, T., Bodas, R., Castro, T., Jimeno, V. \& Mantecon, A.R., 2009. Animal performance and fatty acid composition of lambs fed with different vegetable oils. Meat Sci. 83, 511-516.

Martin, S.A. \& Jenkins, T.C., 2002. Factors affecting conjugated linoleic acid production by mixed ruminal bacteria. Univ. Georgia, CAES, Dept. Anim. Dairy Sci., 2001/2002 Annual report.

McGuire, M.A. \& McGuire, M.K., 2000. Conjugated linoleic acid (CLA): A ruminant fatty acid with beneficial effects on human health. Proc. Am. Soc. Anim. Sci. 1-8. 
Oka, A., Iwaki, F., Dohgo, T., Ohtagaki, S., Noda, M., Shiozaki, Endoh, T.O. \& Ozaki, M., 2002. Genetic effects on fatty acid composition of carcass fat of Japanese Black Wagyu steers. J. Anim. Sci. 80, $1005-1011$.

Rainer, L. \& Heiss, C.J., 2004. Conjugated linoleic acid: Health implications and effects on body composition. J. Am. Diet. Assoc. 104, 963-968.

Reas, K., De Smet, S. \& Demeyer, D., 2004. Effect of dietary fatty acid incorporation of long chain polyunsaturated fatty acids and conjugated linoleic acid in lamb, beef and pork meat: a review. Anim. Feed Sci. Technol. 113, 199-221.

SAS, 1999, SAS ${ }^{\circledR}$ User's Guide. Version 6.12. SAS Institute Inc., Cary, N.C., USA

Sauer, F.D., Fellner, V., Kinsman, R., Kramer, J.K., Jackson, H.A., Lee, A.J. \& Chen, S., 1998. Methane output and lactation response in Holstein cattle with monensin or unsaturated fat added to the diet. J. Anim. Sci. 76, 906-914.

Schmidt, A., Collomb, M., Sieber, R. \& Bee, G., 2006. Conjugated linoleic acid in meat and meat products: A review. Meat Sci. 73, 29-41.

Schollan, N.D., Hocquette, J-F., Nuernburg, K., Dannenberger, D., Richardson, I. \& Moloney, A., 2006. Innovations in beef production systems that enhance the nutritional and health value of beef lipids and their relationship with meat quality. Meat Sci. 74, 17-33.

Wahle, K.W.J., Heys, S.D. \& Rotondo, D., 2004. Conjugated linoleic acids: are they beneficial or detrimental to health? A review. Pro. Lipid Res. 43, 553-587.

Wood, J.D., Enser, M., Fisher, A.V., Nute, G.R., Sheard, P.R., Richardson, R.I., Hughes, S.I. \& Whittington, F.M., 2008. Fat deposition, fatty acid composition and meat quality: A review. Meat Sci. 78, 343-358.

Woods, V.B. \& Fearon, A.M., 2009. Dietary sources of unsaturated fatty acids for animals and their transfer into meat, milk and eggs: A review. Livest. Sci. 126, 1-20.

Wynn, R.J., Daniel, Z.C.T.R., Flux, C.L., Craigon, J., Salter, A.M. \& Buttery, P.J., 2006. Effect of feeding rumen-protected conjugated linoleic acid on carcass characteristics and fatty acid composition of sheep tissues. J. Anim. Sci. 84, 3340-3450. 